\title{
Archaeological ash deposits and soils formed on ash in the south of the East European Plain
}

\author{
Fedor N. Lisetskii ${ }^{\text {a, }}$, Vladimir F. Stolba ${ }^{\mathrm{b}}$ \\ ${ }^{a}$ Institute of Earth Sciences, Belgorod State National Research University, 85 Pobeda, Belgorod, 308015, Russian Federation \\ ${ }^{\mathrm{b}}$ Berlin-Brandenburg Academy of Sciences and Humanities, 22/23 Jägerstrasse, Berlin, D-10117, Germany
}

\section{A R T I C L E I N F O}

\section{Keywords:}

Ash

Ash deposits

Fuel

Pedoarchaeology

Geoarchaeology

Geochemistry

\begin{abstract}
A B S T R A C T
Ash as an anthropogenic substrate is widely found at archaeological sites in the south of the East European Plain. Investigations of archaeological ashes, the results of which are presented here, have been conducted in three regions that differ in climate and extent of forest cover (from 29 to 1.5\%): 1) typical forest-steppe; 2) piedmont forest-steppe with islands of groves; 3) steppe, almost woodless landscapes. Using spectrometry and X-ray analysis, the present study investigates the chemical composition of ancient ash and ash experimentally produced from different sorts of fuel, as well as the geochemistry of soils developed on ash deposits. For ashing, 25 samples of plants that potentially might have been used as fuel were selected, as well as dung from cattle and horses. Using the geometric mean values of concentrations of diagnostic elements, a formula was proposed for evaluating the pedogenetic transformation of ash, which is based on the ratio of accumulation elements $(\mathrm{Cu}, \mathrm{As}, \mathrm{SiO}$, $\mathrm{Al}_{2} \mathrm{O}_{3}$ and $\mathrm{Pb}$ ) and dispersion elements ( $\mathrm{Sr}, \mathrm{Ca}, \mathrm{Co}, \mathrm{Mg}$ and $\mathrm{Na}_{2} \mathrm{O}$ ). The procedure makes it possible to date the pedogenetically transformed ash through the stable associations of chemical elements diagnostic of the geochemical accumulation and dispersion in the soils formed on ash. Geochemical criteria were established for identifying ash that results from the combustion of dung, wood or a combination of different fuels. This study opens prospects for further research into archaeological ash deposits in varying cultural, temporal and environmental conditions.
\end{abstract}

\section{Introduction}

The pyrogenic processes and related combustion products have had considerable influence on the micromorphology and mineral composition of archaeological deposits (Courty et al., 1989; Canti, 2003). Ash as a common component of archaeological deposits, along with different methods of identification of its sources, is considered in a number of studies (Braadbaart et al., 2012, 2017; Powell et al., 2012; Shahack-Gross and Ayalon 2013; Mentzer, 2014; Kovács et al., 2017). As various plant taxa and other fuels differ in their elemental composition, chemical analysis of ash, along with other methods, is an important tool for identifying different types of fuel (Hillis, 1987; Etiégni and Campbell, 1991; Steenari et al., 1999; Canti, 2003; Liodakis et al., 2005; Miller and Miller, 2007; Ntinou and Tsartsidou, 2017). In the northern Black Sea region, the chemical composition of "ashy" deposits has only been studied in Moldova, in connection with archaeological sites of the Noua-Sabatinovka cultural complex (Daszkiewicz and Schneider, 2011; Demkin, 2011; Facklam, 2011) and some sites in Crimea (Lisetskii and
Ergina, 2010; Lisetskii et al., 2016). Identification of various fuels contributes to a better understanding of the palaeoecological conditions and economic activities of ancient societies. Assessing the pedogenic transformation of ashy deposits makes it possible to establish their age and the age of related cultural strata, which is particularly valuable when other datable archaeological material is absent.

As a common attribute of human habitations, special ash deposits, the so-called "zol'niki" or ashy mounds, are known in the vast territory from the Southern Ural through the Danube Region, ranging in date from the Bronze Age to the late medieval and sub-modern periods (Kruglikova, 1975; Rusanova, 1998; Sava, 2005a; Rusjaeva, 2006; Nosova, 2008; Stolba and Andresen, 2015; Kovalčuk, 2015). In the north-western and northern Black Sea regions, such ashy deposits are particularly characteristic of the Noua and Sabatinovka cultures, as well as the subsequent cultures of the late Bronze Age and early Iron Age (Belogrudovka, Belozerka and Chernoles cultures). In the Greek settlements of the Black Sea coast and in the Scythian settlements of the forest-steppe zone, they also constituted a notable feature of their

\footnotetext{
* Corresponding author.

E-mail address: liset@bsu.edu.ru (F.N. Lisetskii).
} 
cultural landscape. In the ancient city of Olbia, ash has been used in the layered foundations of its buildings, while in the city's rural territory it served as fertilizer (Lisetskii and Rodionova, 2015). In Crimea, the soils rich in ash and ashy deposits occupy an area of 14,200 ha, including 2100 ha of ploughed land (Kogel', 1969). The height of ashy mounds varies from 0.5 to 2 to $10-13 \mathrm{~m}$ (Kruglikova, 1975; Dirin, 1896, 120; Stolba and Andresen, 2015). Their number varies too, amounting at the Bronze Age sites and the Scythian settlements of the forest-steppe zone to 10-25 and occasionally over 50 (Petrenko, 1989; Sava, 2005a; Sava and Kaiser, 2011). The youngest ashy deposits are recorded at the abandoned, mainly Tatar and Russian, rural settlements of the 18th through the first half of the 20th century.

While the nature of the Bronze Age and Early Iron Age ashy mounds in the northern Black Sea region remains a matter of debate, the three principal hypotheses explain them as: 1) household waste, 2) places of cult and ritual activities or 3 ) the ruins of dwellings covered with ashy remains (Rusanova, 1998; Belozor, 2012; Gerškovič, 1999, 2004). With regard to the "zol'niki" of the Noua and Sabatinovka cultures, it has been argued that they contain no proper ash, as no visual traces of burning could be discerned and the content of $\mathrm{C}_{\mathrm{org}}(2.1-2.3 \%)$ is relatively high (Daszkiewicz and Schneider, 2011; Demkin, 2011). According to this hypothesis, each "ashy mound" conceals the remains of an estate, and the deposits of the characteristic light-grey "ashy" colour are the naturally decayed organic remains of plant or animal origin (straw, grass, etc.) accumulated in households by the time they were abandoned (Gerškovič, 2004; Sava and Kaiser, 2011). The economic structure of these societies, which practiced transhumance, periodically changing settlement places, is thought to account for the large number of sites with "zol'niki" in this region (Gershkovich, 2003).

Traditional sources of fuel in forestlands are wood and peat. In the steppe regions, where resources of firewood are limited, the need for fuel was compensated by alternative sources. According to Herodotus, animal bones were one of the alternative sources of fuel among the nomads of the northern Black Sea region (Hdt. 4.61; Godley, 1920). Of special importance was, traditionally, also the dung of herbivore animals, the use of which as fuel is recorded in different parts of the globe from the Neolithic to modern day (Miller, 1984; Brink, 2008; Mlekuž, 2009; Shahack-Gross, 2011; Portillo et al., 2017). Also in Crimea, this practice is well-documented (Çelebi, 2008; Stolba and Andresen, 2015). According to the mid-19th century ethnographic descriptions, manuring was alien to the agricultural practices of the Crimean Tatars, all the dung being used as fuel (Radde, 1856). Ash was not used as a fertilizer either, being brought by the villagers to the common ash mounds. These ash mounds, which reached $2 \mathrm{~m}$ and more in height, constituted an important feature of the natural and cultural landscape of the Tatar villages.

The ready fuel (Russ. kizyak, Turk. tezek) was a mixture of dung and straw. After drying, the stores of kizyak were kept in the homestead courtyards, forming long, oval, up to $2 \mathrm{~m}$-high heaps that were daubed with fresh excrements as protection against moisture (Radde, 1856). According to Radde, the quality of the sheep dung kizyak is higher than that of cattle dung, and its heat emission is higher than that of the European beech (Fagus silvatica). As demonstrated experimentally, even though cow dung can produce a higher temperature than the sheep dung (up to $630^{\circ} \mathrm{C}$ and $570^{\circ} \mathrm{C}$ correspondingly), the latter burns longer (Shahack-Gross et al., 2005; Shahack-Gross, 2008).

An important advantage of this fuel for nomadic and agricultural communities is its wide availability. According to the archaeozoological evidence from the south of the East European Plain, cattle clearly dominated in the Bronze Age herds, making in some places up to $44 \%$ of the total (Bibikova, 1970; Kolotuchin, 1996, 2003; Gershkovich, 2003; Sava, 2005b; Sava and Kaiser, 2011; Lisetskii et al., 2017). Calculations suggest that one cow is able to produce about $10,000 \mathrm{~kg}$ of dung annually, while one sheep yields over $500 \mathrm{~kg}$ per year or about $1.5 \mathrm{~kg}$ per day (Slicher van Bath, 1963; Mlekuž, 2009).

In this work, we aim to experimentally investigate the chemical composition of the potential ancient fuels and identify the differences in types of ash and the soils formed on ashy strata in various regions of the East European Plain that differ in vegetation cover. Attempts have also been made to work out criteria for identifying ash and its genetic types, as well as to develop a method for dating ashy deposits.

\section{Research area}

Investigations of ash from the cultural strata of archaeological sites were conducted in three regions that differ significantly in climate and vegetation cover: 1) typical forest-steppe with hill groves on the right bank of the Vorskla River $\left(50^{\circ} 37^{\prime} 15.5^{\prime \prime} \mathrm{N}, 36^{\circ} 0^{\prime} 13.4^{\prime \prime} \mathrm{E}\right.$; average annual temperature $6.1^{\circ} \mathrm{C}$, annual precipitation $574 \mathrm{~mm}$ ); 2) forest-steppe of piedmont Crimea with islands of groves (an area with coordinates from $45^{\circ} 7^{\prime} 2.0^{\prime \prime} \mathrm{N}, 34^{\circ} 38^{\prime} 5.8^{\prime \prime} \mathrm{E}$ to $45^{\circ} 8^{\prime} 28.5^{\prime \prime} \mathrm{N}, 34^{\circ} 39^{\prime} 52.5^{\prime \prime} \mathrm{E}$ ) with an average annual temperature of $10.3^{\circ} \mathrm{C}$ and an annual precipitation of $450 \mathrm{~mm}$; 3) steppe landscapes of north-western Crimea $\left(45^{\circ} 29^{\prime} 21.3^{\prime \prime} \mathrm{N}\right.$, $32^{\circ} 43^{\prime} 17.9^{\prime \prime} \mathrm{E}$ ) with an average annual temperature of $9.8-10.2^{\circ} \mathrm{C}$ and an annual precipitation of $340 \mathrm{~mm}$.

Palaeopedological and palaeobotanical data from the forest-steppe of the Central Russian Upland suggests that the landscapes with deciduous forest on watersheds began to develop as early as the late SubBoreal (3500-2800 BP) (Čendev et al., 2014). Prior to the economic development of the Vorskla River region in the first half of the 17th century, woodlands amounted to $40 \%$ of the total area (Matveev et al., 2017), in contrast to only $29 \%$ at present. In Crimea, woodland makes up only $11.5 \%$ of the total area, the majority of which (66.5\%) is represented by oak forests. For the area of Pantikapaion in eastern Crimea, Theophrastus, the 4th-century BC author of Historia Plantarum (HP 4.5.3; Hort, 1916), attests a number of deciduous species, including oak, elm, ash and others, but no pines or firs. For other parts of Crimea, no such literary evidence is available. In north-western Crimea, at present, no oak or pine grows in natural conditions, arboreal and shrub vegetation being found only at the bottoms of larger ravines $(1.5 \%$ of the total area). However, the finds of charred wood, along with pollen and the archaeozoological data from archaeological sites, testify to the presence of oak, maple, elm, hazel, hornbeam, juniper, alder, poplar and other deciduous trees in the 4 th-1st centuries BC, as well as to the presence of forest-steppe fauna (Levkovskaja, 1970; Maslov and Filin, 1976; Ščeglov, 1978; Podgorodeckij, 1979; Hannestad, 2007; Stolba, 2014. For the finds of the phytoliths of coniferous trees at the classical and Bronze-Age sites in the area, see Lisetskii et al., 2020). Geoarcheological and palinological studies in the area of ancient Chersonesos also suggest that in the period of the Greek colonisation, the territory of south-western Crimea must have been considerably more wooded than now (Cordova and Lehman, 2003). In the central part of Crimean piedmonts (Belogorsk District), woodland makes up $29.4 \%$ of the total area, of which only 12 small oak grove plots are protected (Garkusha and Bagrova, 2012). Buried forest soils discovered under the 4th century BC Scythian barrows suggest that these are the remnants of ancient forestland deforested by humans.

\section{Data and methods}

\subsection{Archaeological sites with ash deposits}

Sampling ash deposits (A) and soils formed on ash (S) in the south of the East European Plain (Fig. 1) was carried out in each of the soilstratigraphic sections at archaeological sites of different ages. Most indicative stratigraphic columns with ash deposits and soils formed on them are presented in supplementary materials (Figs. S2-S4).

In Region 1, our investigations were focused on the fortified settlement of Borisovka situated in the forest-steppe zone, in the basin of the Vorskla River (Belgorod Oblast). The Scythian settlements of this region fall into two chronological groups: the early group (7th-5th century BC) and the late group (5th-3rd century BC) (Moruženko, 1985). In a soil 

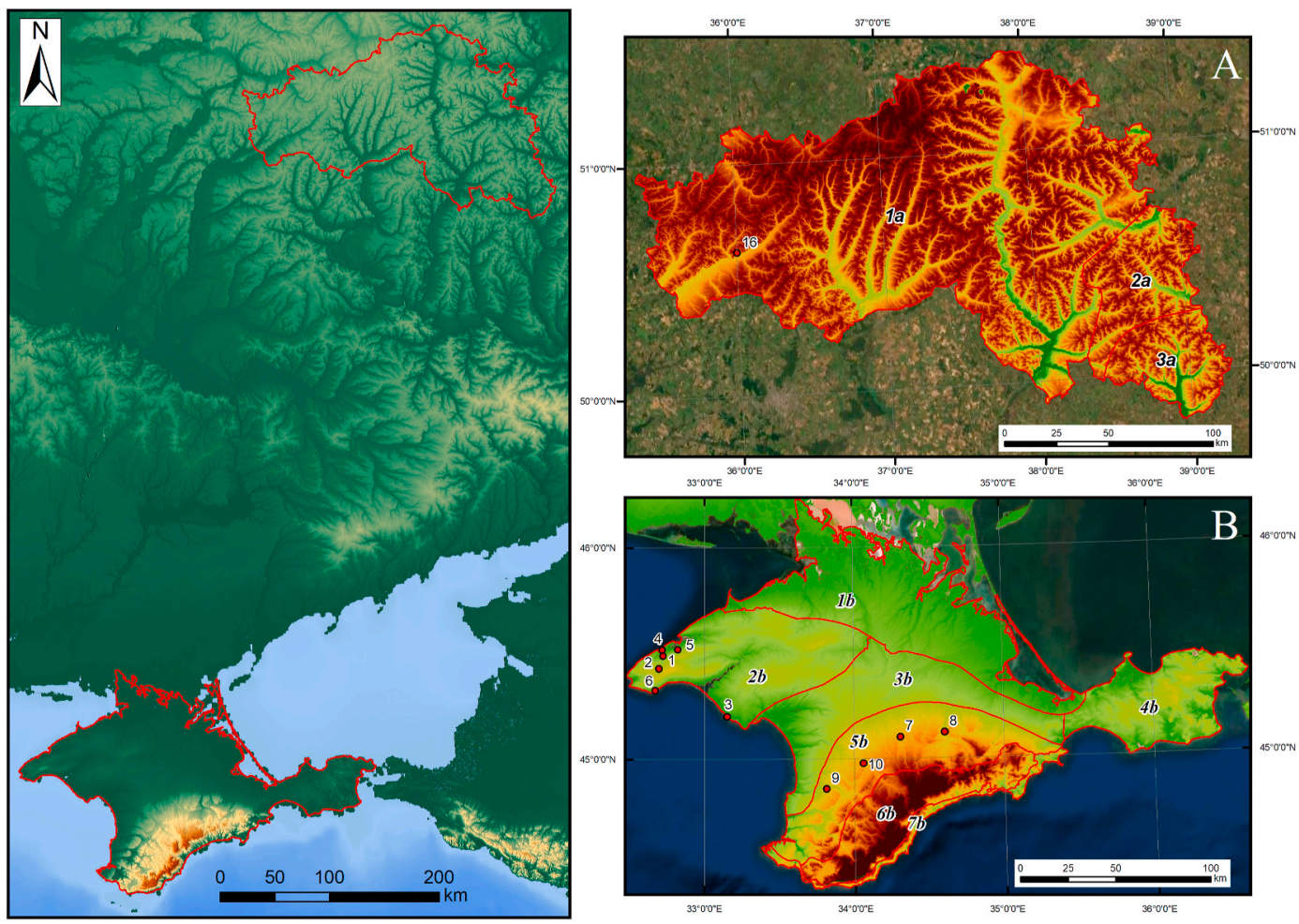

Fig. 1. Location of research objects (ashy soils and ash deposits) in the continental forest-steppe, Belgorod Oblast (A) and in the Plain (steppe) and Piedmont (foreststeppe) Crimea (B). Archaeological sites: Borisovka, mid-5th c. BC (16); Multiperiod settlement S11-022 (1); Kunan, 2nd c. BC (2); Airchi, 2nd c. BC - 1st c. AD (3); Kalos Limen, 4th c. BC - 2nd c. AD (4); former village of Saya, before 1944 (5); former village of Oirat, before 1944 (6); Borut-Khane, 1st c. BC - 1st c. AD (7); AkKaya, c. 225-250 AD (8); Zayachye, 2nd - 3rd c. AD (9); Kermen-Kyr, 2nd - 3rd c. AD (10). Natural areas: 1a - Typical forest-steppe; 2a - Southern forest-steppe; 3a Steppe; $1 \mathrm{~b}$ - North Crimean lowland steppe; $2 \mathrm{~b}$ - Tarkhankut elevated plain; $3 \mathrm{~b}$ - Central Crimean plain steppe; $4 \mathrm{~b}$ - Kerch hilly-ridged steppe; $5 \mathrm{~b}$ - Foothill foreststeppe; $6 \mathrm{~b}$ - Main ridge, mountainous meadows and forests; $7 \mathrm{~b}$ - Southern Coast.

section made at the periphery of the Borisovka settlement (A16), an ashy layer dating to the mid-5th century BC was excavated to a depth of 1.0 m.

In Region 2 (Piedmont Crimea), the late Scythian fortified settlements of Borut-Khane, Ak-Kaya (Fig. 2) and Kermen-Kyr, as well as the unfortified settlement of Zayachye, were investigated (Fig. 1, nos. 7-10). At Borut-Khane, which dates to the period from the 3rd-2nd century BC to the 1st century AD (Smekalova et al., 2017), several ash mounds measuring from 0.5 to $2.0 \mathrm{~m}$ in height were identified. At this site, near the rampart, at the depth of $46-98 \mathrm{~cm}$, a layer of pure ash was also discovered. A sample of ash for chemical analysis was taken from the depth of $63-73 \mathrm{~cm}$ (A167). The modern forest tracts, closest to the settlement, are situated at a distance of $4.3 \mathrm{~km}$. For the regional reconstruction of the palaeogeographic conditions, we also used the data on the buried soils and wood remains uncovered under the tumuli, in particular under the burial mound of Ak-Kaya IX. The main burial of the kurgan, dating to 350-325 BC, was covered with oak logs. A sample of ancient wood for experimental ashing was taken from a log of $42-47 \mathrm{~cm}$ in circumference (P22).

Object numbers (ash [A], soils formed on ash [S]) are consistent with Table 1.

In Region 3 (north-western Crimea), archaeological sites sampled for ash (Fig. 1, nos. 1-6). included a multi-period, Bronze Age and Early Iron Age settlement S11-022, the Hellenistic and Roman period sites of Kunan, Airchi and Kalos Limen, and the abandoned sub-modern Tatar villages of Saya $\left(45^{\circ} 31^{\prime} 7.9^{\prime \prime} \mathrm{N}, 32^{\circ} 49^{\prime} 14.5^{\prime \prime} \mathrm{E}\right.$; Table 1 , no. S5) and Ojrat

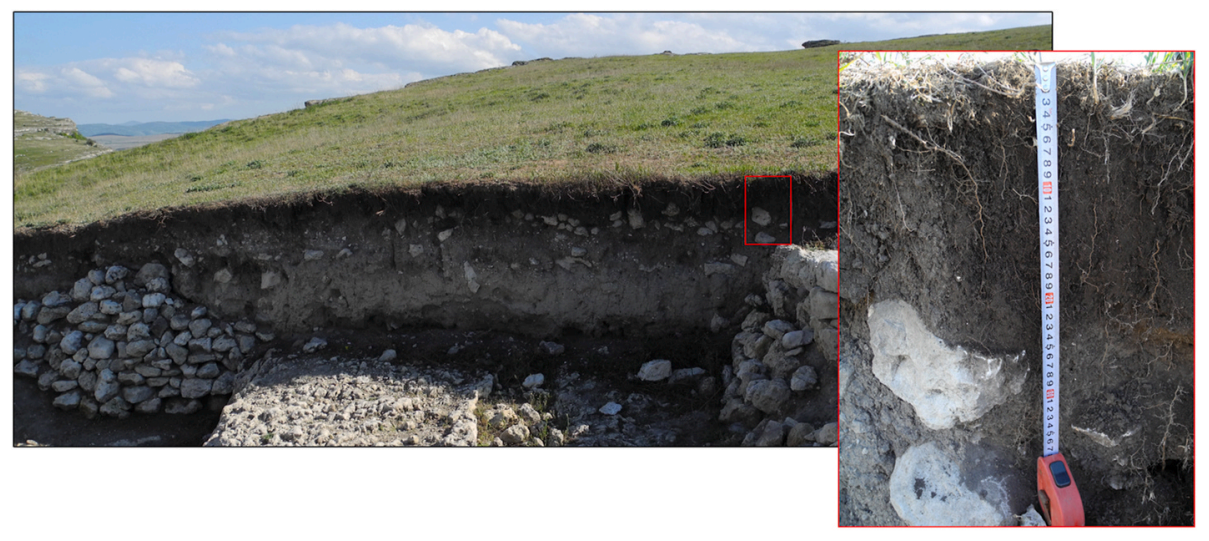

Fig. 2. Ancient settlement of Ak-Kaya (Piedmont Crimea; excavations by Yu.P. Zaitsev). The soils formed after the demise of the settlement (c. 225-250 AD); the thickness of horizon A: $0-23 \mathrm{~cm}$, of horizon AB: $23-34 \mathrm{~cm}$. The depth of the ash deposit: 34-80 cm below the modern top-surface. 
Table 1

Objects of study at archaeological sites of three investigated regions (soils formed on ash [S] and ash from cultural strata [A]).

\begin{tabular}{|c|c|c|c|c|}
\hline No. & Object & $\begin{array}{l}\text { Place of } \\
\text { sampling }\end{array}$ & $\begin{array}{l}\text { Horizon, depth } \\
(\mathrm{cm})\end{array}$ & $\begin{array}{l}\text { Soil colour, } \\
\text { Munsell } \\
\text { (dry) }\end{array}$ \\
\hline \multirow[t]{3}{*}{$\mathrm{S} 1 / 1$} & \multirow{3}{*}{$\begin{array}{l}\text { Settl. S11-022, } \\
\text { area of } \\
\text { Chernomorskoe }\end{array}$} & \multirow{3}{*}{$\begin{array}{l}\text { Soil on ash; } \\
\text { archaeological } \\
\text { horizon of the } \\
\text { 10th c. BC }\end{array}$} & Hor. A, 0-18 & 10 YR 5/2 \\
\hline & & & Hor. $\mathrm{AB}, 18-50$ & 10 YR $6 / 2$ \\
\hline & & & Ash, $>50$ & 10 YR $7 / 2$ \\
\hline \multirow[t]{4}{*}{$\mathrm{S} 1 / 2$} & \multirow[t]{4}{*}{ Settl. S11-022 } & \multirow[t]{4}{*}{ Soil on ash } & Hor. A, 5-26 & 10 YR $5 / 3$ \\
\hline & & & $\begin{array}{l}\text { Hor. AB, } \\
26-55.5\end{array}$ & 10 YR 5/2 \\
\hline & & & Hor. B1, 47-55.5 & 10 YR $5 / 2.5$ \\
\hline & & & Ash, 55.5-60.5 & 10 YR $6 / 2.5$ \\
\hline \multirow[t]{2}{*}{$\mathrm{A} 1 / 3$} & \multirow[t]{2}{*}{ Settl. S11-022 } & \multirow{2}{*}{$\begin{array}{l}\text { Cultural layer } \\
\text { containing ash } \\
\text { (section, } 2 \mathrm{~m} \mathrm{~W} \\
\text { of stone } \\
\text { structure) }\end{array}$} & $\begin{array}{l}\text { Hor. C. Top } \\
\text { section of the } \\
\text { layer }(60-70 \mathrm{~cm})\end{array}$ & 10 YR $6 / 2$ \\
\hline & & & $\begin{array}{l}\text { Hor. C. Lower } \\
\text { section of the } \\
\text { layer }(80-90 \mathrm{~cm})\end{array}$ & 10 YR 6/2 \\
\hline $\mathrm{A} 2 / 1$ & $\begin{array}{l}\text { Kunan, 2nd c. } \\
\text { BC }\end{array}$ & $\begin{array}{l}\text { Ash intercalation } \\
\text { with traces of } \\
\text { fire }\end{array}$ & $39-41$ & 10 YR 5/1.5 \\
\hline $\mathrm{A} 2 / 2$ & $\begin{array}{l}\text { Kunan, 2nd c. } \\
\text { BC }\end{array}$ & $\begin{array}{l}\text { Cultural layer } \\
\text { with ash }\end{array}$ & $>41$ & 10 YR 5/3 \\
\hline $\mathrm{A} 3 / 1$ & $\begin{array}{l}\text { Airchi, 2nd c. BC } \\
-1 \text { st c. AD }\end{array}$ & Defensive ditch & 235 & 10 YR $7 / 1$ \\
\hline $\mathrm{A} 3 / 2$ & $\begin{array}{l}\text { Airchi, 2nd c. BC } \\
-1 \text { st c. } \mathrm{AD}\end{array}$ & $\begin{array}{l}\text { A } 3.5-3.8 \mathrm{~m} \\
\text { wide and } 1.2 \mathrm{~m} \\
\text { deep pit with a } \\
33 \mathrm{~cm} \text { thick layer } \\
\text { of ash }\end{array}$ & 200 & 10 YR $6 / 2$ \\
\hline $\mathrm{A} 3 / 3$ & $\begin{array}{l}\text { Airchi, 2nd c. BC } \\
-1 \text { st c. AD }\end{array}$ & $\begin{array}{l}\text { Hearth ( } 93 \times 41 \\
\mathrm{~cm}) \text {; ash on the } \\
\text { hearthstone }\end{array}$ & 152 & 10 YR 6/4 \\
\hline $\mathrm{A} 4 / 1$ & $\begin{array}{l}\text { Kalos Limen, } 1 \text { st } \\
\text { c. } \mathrm{BC}-1 \text { st c. } \mathrm{AD}\end{array}$ & Top of ashy layer & Hor. A, 0-22 & 10 YR 6/2 \\
\hline $\mathrm{A} 4 / 2$ & $\begin{array}{l}\text { Kalos Limen, 4th } \\
\text { c. BC-2nd c. AD }\end{array}$ & $\begin{array}{l}\text { Citadel (late } \\
\text { 3rd-2nd c. BC), } \\
\text { cultural stratum }\end{array}$ & $>20$ & 10 YR $7 / 2$ \\
\hline S5 & $\begin{array}{l}\text { Former village } \\
\text { of Saya, before } \\
1944\end{array}$ & Top of ashy layer & $\begin{array}{l}20 \\
50\end{array}$ & $\begin{array}{l}10 \text { YR } 5 / 2.5 \\
10 \text { YR } 5 / 3\end{array}$ \\
\hline S6 & $\begin{array}{l}\text { Former village } \\
\text { of Oirat, before } \\
1944\end{array}$ & Top of ashy layer & $\begin{array}{l}\text { Hor. A, 0-16 } \\
\text { Hor. AB 16-28 }\end{array}$ & $\begin{array}{l}10 \text { YR 6/2 } \\
10 \text { YR 6/2 }\end{array}$ \\
\hline A7 & $\begin{array}{l}\text { Borut-Khane, } 1 \text { st } \\
\text { c. } \mathrm{BC}-1 \text { st c. } \mathrm{AD}\end{array}$ & $\begin{array}{l}\text { Ash deposit } \\
\text { ("zol'nik") }\end{array}$ & Hor. B1, > 37 & 10 YR 6/2 \\
\hline A167 & $\begin{array}{l}\text { Borut-Khane, 1st } \\
\text { c. BC }-1 \text { st c. AD }\end{array}$ & Rampart & Ash, 63-73 & 10 YR $7 / 1$ \\
\hline A8 & $\begin{array}{l}\text { Ak-Kaya, } \\
\text { 225-250 AD }\end{array}$ & Settlement & Hor. B1, >33.5 & 10 YR 6/2 \\
\hline A9 & $\begin{array}{l}\text { Zayachye, 2nd - } \\
\text { 3rd c. AD }\end{array}$ & Village & Hor. B1, > 32 & 10 YR 6/1 \\
\hline A10 & $\begin{array}{l}\text { Kermen-Kyr, } \\
\text { 2nd - 3rd c. AD }\end{array}$ & Settlement & Hor. B1, 30-35 & 10 YR $6 / 1$ \\
\hline A16 & $\begin{array}{l}\text { Borisovka, mid- } \\
5 \text { th c. BC }\end{array}$ & Settlement & Ash, 62-72 & 10 YR $6 / 2$ \\
\hline
\end{tabular}

$\left(45^{\circ} 19^{\prime} 37.0^{\prime \prime} \mathrm{N}, 32^{\circ} 40^{\prime} 14.3^{\prime \prime} \mathrm{E}\right.$; Table 1 , no. S6). Unlike the short-lived fortified Greek farmhouse of Kunan, where only two habitation phases were distinguished, i.e. of the second half of the 4th through the early 3rd century BC and of the last third of the 3rd through the mid-2nd century BC (Smekalova and Stolba, 2009), the chronology of Kalos Limen and Airchi is considerably broader, including also the Roman period. At Kunan, the upper ashy horizon bears witness of a fire that destroyed the farmhouse in the mid-2nd century BC (Smekalova and Kutajsov, 2017). The objects sampled at the fortified coastal settlement of Airchi, situated $9 \mathrm{~km}$ west of Yevpatoriya, included an ashy fill of a household pit and a well-preserved late-Scythian furnace, which was discovered at a depth of $1.5 \mathrm{~m}$ (Fig. 3) and penetrated the cultural layer of the Hellenistic period. Ash sample A3/3 has been taken at the bottom of this furnace.

\subsection{Plant and dung samples}

In 2016, 25 samples of arboreal and grass plants (P no.) that potentially could have served as fuel were taken for experimental ashing (Table 2). These were collected in the ravines of the Tarkhankut Peninsula (P1-9), in the Vorontsov Park of the township of Chernomorskoe (P10-13) and in the Belogorsk District of Crimea (P25, P22). Further, cattle and horse dung has been collected on pastures in the Chernomorskoe district of Crimea (Region 3). Moreover, in the typical forest-steppe of the Belgorod region, five types of arboreal species that no longer grow in the natural conditions of the Tarkhankut Peninsula were collected. The collection of plants selected for experimental ashing and chemical analysis was supplemented by a typical ash sample (A167) that comes from the foothill forest-steppe, where both wood and manure could be used as fuel.

\subsection{Geochemical methods for the study of soils and ash}

The chemical composition of ash prepared from plant samples was investigated using a variety of techniques, including emission spectrometry ( $\mathrm{Zn}, \mathrm{Cu}, \mathrm{Mn}$ and $\mathrm{Co}$; spectrometer ICPE-9000 with inductionbound plasma), atomic absorption spectroscopy ( $\mathrm{Pb}$ and $\mathrm{Cd}$ : spectrometer Quant-2AT; Hg: spectrometer Quant-Z) and photocolorimetry (As; photocolorimeter KFK-3-01). Ashing of samples was carried out in a muffle furnace at $450{ }^{\circ} \mathrm{C}$. To facilitate accurate comparison of the results, the same methods were used to analyse sample A167 that derives from an archaeological site. Colours of ash and soil (dry and moist) were recorded using the Munsell system.

Chemical analyses of soils included the following standard procedures (Arinushkina, 1970): the $\mathrm{C}_{\text {org }}$ content by Tyurin's method (by oxidation with a solution of potassium dichromate in sulphuric acid); $\mathrm{CO}_{2}$ in carbonates by acidometry; $\mathrm{pH}\left(\mathrm{H}_{2} \mathrm{O}\right)$ by potentiometric method; the available $\mathrm{P}_{2} \mathrm{O}_{5}\left(\mathrm{mg} \cdot \mathrm{kg}^{-1}\right)$ by Machigin's method (spectrophotometer UNICO-1200), and $\mathrm{K}_{2} \mathrm{O}$ on a fiery photometer. The determination of cation exchange capacity (CEC) in calcareous soils was performed using EDTA-Na $a_{2}$.

Concentrations of 22 chemical elements in ash and soils were determined by measuring the fractions of metal mass and oxides in powdered samples using XRF by a spectrometer Spectroscan Max-GV. Chemical elements analysed included ten macroelements (Ca, Si, Al, Fe, $\mathrm{Ti}, \mathrm{Mn}, \mathrm{Mg}, \mathrm{P}, \mathrm{K}, \mathrm{Na}$ ) and twelve trace elements ( $, \mathrm{Cr}, \mathrm{Ni}, \mathrm{Co}, \mathrm{Cu}, \mathrm{Zn}, \mathrm{As}$, $\mathrm{Sr}, \mathrm{Pb}, \mathrm{Ba}, \mathrm{Zr}, \mathrm{Rb})$.

Using these data, the value of $\mathrm{SiO}_{2} /\left(\mathrm{RO}+\mathrm{R}_{2} \mathrm{O}\right)$, which characterizes the degree of the eluviation, was calculated by the formula:

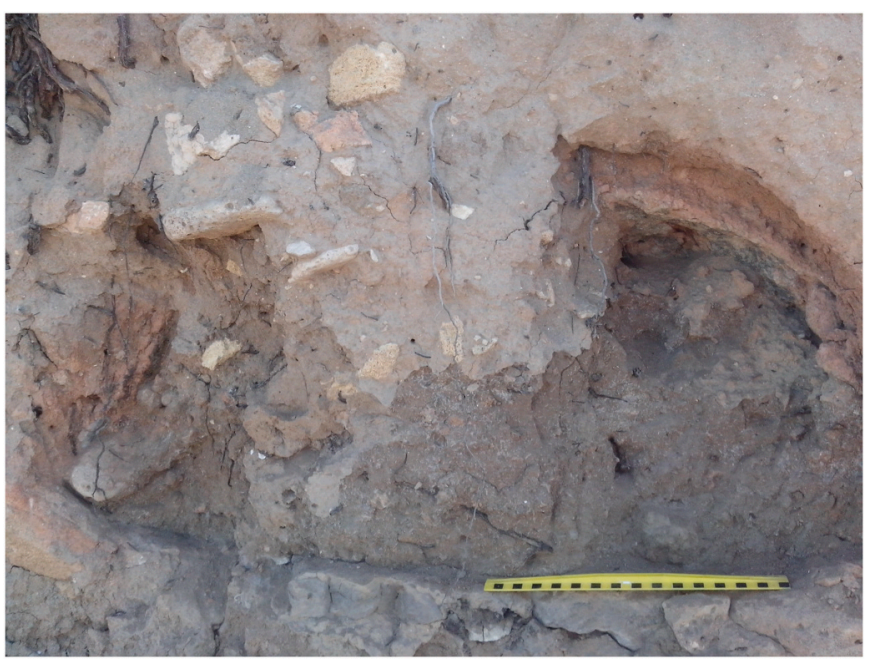

Fig. 3. Ash sampling spot in the 2nd cent. BC-1st cent. $A D$ furnace at the Airchi settlement. 
Table 2

Plant (P1-18, P21-26 and P28) and dung (P19 and P20) samples used for ashing.

\begin{tabular}{|c|c|c|c|}
\hline No. & Plants/dung types & Plant parts & Munsell; dry \\
\hline P1 & Crataegus taurica Pojark. & wood & 10 YR $6 / 1$ \\
\hline P2 & Salsola australis $\mathrm{R} . \mathrm{Br}$ & stalks & 10 YR $5 / 1$ \\
\hline P3 & Ligustrum vulgare L. & wood & 10 YR $5 / 1$ \\
\hline P4 & Juniperus foetidissima Willd. & wood & 10 YR $5 / 1$ \\
\hline P5 & Malus praecox (Pall.) Borkh. & wood & 10 YR $5 / 1$ \\
\hline P6 & Pyrus pyraster Burgsd. & wood & 10 YR $5 / 1$ \\
\hline P7 & Prunus spinosa L. & wood & 10 YR $5 / 1$ \\
\hline P8 & Artemisia taurica Willd. & stalks & 10 YR $5 / 1$ \\
\hline P9 & Padellus mahaleb (L.) Vass. & wood & 10 YR $5 / 1$ \\
\hline $\mathrm{P} 10$ & Quercus pubescens Willd. & wood & 10 YR $5 / 1$ \\
\hline P11 & Carpinus betulus $\mathrm{L}$. & wood & 10 YR $6 / 1$ \\
\hline P12 & Ulmus minor Mill. & wood & 7.5 YR 3/0 \\
\hline P13 & Fraxinus pennsylvanica Marsh. & wood & 10 YR $6 / 1$ \\
\hline P14 & Acer campestre $\mathrm{L}$. & wood & 10 YR $6 / 1$ \\
\hline P15 & Sorbus aucuparia L. & wood & 2.5 YR $3 / 0$ \\
\hline P16 & Populus nígra $\mathrm{L}$. & wood & 10 YR $5 / 1$ \\
\hline P17 & Salix fragilis $\mathrm{L}$. & wood & 2.5 YR $2.5 / 0$ \\
\hline P18 & Tilia cordata Mill. & wood & 10 YR 4/1 \\
\hline P22 & Quercus pubescens Willd. & wood & 10 YR $8 / 1$ \\
\hline P25 & Pinus pallasiana $\mathrm{D}$. Don & wood & 10 YR 4/1 \\
\hline P21 & Vitis & $\begin{array}{l}\text { base of the } \\
\text { trunk and } \\
\text { vine }\end{array}$ & 10 YR $5 / 1$ \\
\hline P23 & Phragmites australis (Cav.) Trin. ex Steud. & stalks & 7.5 YR $2 / 0$ \\
\hline P24 & Herbs; Stipa capillata L. & grass & 2.5 YR 3/0 \\
\hline P26 & Hordeum vulgare L. & straw & 2.5 YR $3 / 0$ \\
\hline P28 & $\begin{array}{l}\text { Grasses; Setaria glauca (L.) P. Beauv., } \\
\text { Festuca pratensis Huds. }\end{array}$ & $\begin{array}{l}\text { decayed } \\
\text { grass }\end{array}$ & 2.5 YR $3 / 0$ \\
\hline P19 & Cattle dung on pastures & kizyak & 10 YR $5 / 1$ \\
\hline P20 & Horse dung on pastures & kizyak & 10 YR $5 / 1$ \\
\hline A167 & Ash layer, Borut-Khane settl. & $\begin{array}{l}\text { ash from } \\
\text { the depth of } \\
63-73 \mathrm{~cm}\end{array}$ & 10 YR $7 / 1$ \\
\hline
\end{tabular}

$\mathrm{SiO}_{2} /\left(\mathrm{RO}+\mathrm{R}_{2} \mathrm{O}\right)=\mathrm{SiO}_{2} /\left[(\mathrm{CaO}+\mathrm{MgO})+\left(\mathrm{K}_{2} \mathrm{O}+\mathrm{Na}_{2} \mathrm{O}\right)\right]$

Using the method of a geometric mean calculation, the duration of the pedogenetic transformation of ash ( $\mathrm{T}$, years) can be determined by the following expression:

$T=\frac{\left(P_{1}^{n} E L_{i}\right)^{1 / n}}{\left(P_{1}^{n} E A_{i}\right)^{1 / n}}$,

where $\mathrm{P}$ is product, $\mathrm{EL}_{\mathrm{i}}$ is dispersed elements in the ash soil, and $\mathrm{EA}_{\mathrm{i}}$ is accumulated elements in the ash soil.

The dating of soils was carried out using the method of pedogenetic chronology that is based on the regional chronofunction of the humus horizon formation of the soil (Lisetskii et al., 2016). Grouping of the objects (samples of the plant and dung ash, ash soils) is based on the most informative chemical elements, using cluster analysis (unification by Ward's method, on the criterion of squared Euclidean distance) normalized by mean-square deviation.

\section{Results and discussion}

\subsection{Comparison of chemical properties of ash and soils formed on ash}

The studied soils have different zero-moment of pedogenesis, which makes it difficult to classify them generally. However, the principles used for the classification of volcanic ash soils according to the World Reference Base for Soil Resources (WRB) Classification (FAO, 1998; Takahashi and Shoji, 2002) permit to term the different-age soils of our study Calcic Chernozems formed on ashy deposits.

The analysis of ash from a deposit at the former village of Ojrat (S6) gives an idea about its granulometric composition. The soils formed on ash contain $70-71 \%$ of particles with a size of $>0.05 \mathrm{~mm}$ (sand) and $2-8 \%$ of particles measuring $<0.002 \mathrm{~mm}$ (clay), which makes it possible to classify them as loam.

Ash of archaeological sites (Table 3 ) is characterized by its grey, light grey and light brownish grey colour. Due to both leaching and fixation in the mineral part of soil formation products, the soils formed on ashy substrates become more brownish: from light brownish grey (10 YR 6/2) to greyish brown (10 YR 5/2). The ash from a fireplace of the Late Scythian period (A3/3) differs from all other samples by its light yellowish brown colour (10 YR 6/4) and, as will be shown below, by its chemical composition.

Compared to ash deposited at a greater depth, soils formed on ash are richer in organic carbon, labile phosphorus and potassium, and if the initial reaction of the solutions was weakly alkaline, it becomes strongly alkaline over time. This shows a significant transformation of ash in the process of pedogenesis.

Comparing the chemical properties of ashy soils and ash with those of the background arable Chernozem $(0-20 \mathrm{~cm}$ ) (Table 3) confirms the well-known opinion about the ash fertilization effect on soils. Ashy soils of different age are on average 85 times richer in labile phosphorus, 31 times in exchangeable potassium, and 1.7 times in organic carbon, as compared to the arable horizon of loamy Chernozems.

\subsection{Colour and chemical characteristics of ash from the sites of different age}

The colour of ash from sampled archaeological sites varies from grey to light grey or light brownish grey. The diagnostic hue of the ash - grey, greyish brown or, more frequently, light brownish grey (10 YR 6/2) appears after drying due to an increase in intensity (value) and a decrease in hue (chroma) (on average, two and one units on the Munsell scale respectively). One of its main physical properties is its low density, which, even after having been buried for a long time, remains lower than that of the soils. According to our observations, the density of ash in the subsoil strata of the Crimean ash deposits varies from 0.68 to $0.92 \mathrm{~g}$ $\mathrm{cm}^{-3}$.

At a multi-period settlement S11-022 where soil sections S1/1, S1/2 and A1/3 (see Table 1 ) had been made, ash samples from different depths were compared.

In section $\mathrm{S} 1 / 1$, horizon $\mathrm{A}(0-18 \mathrm{~cm})$, the soil colour varied from dark greyish brown (moist) to greyish brown (dry). The reaction of the soil solution throughout the entire profile was medium alkaline. Horizon BC was an unstructured, powder-like ashy stratum coloured from yellowish brown (moist) to light grey (dry), which also had the highest content of carbonates.

The stratigraphy of $\mathrm{S} 1 / 2$ and other Bronze Age sites in this region demonstrates that the strata of light brown ash (10 YR 6/2) are always overlaid by the strata of light grey ash ( 10 YR $7 / 2$; dry), thus suggesting their relative chronology. The difference in colour also seems to suggest different geneses of these ashy horizons. The geochemical analysis (by 22 chemical elements) of the light grey ash from section S1/1 and light brown ash from $\mathrm{A} 1 / 3$, and an integral evaluation of their relative differences, demonstrate how they differ, first of all in a higher $(>60 \%)$ content of $\mathrm{Pb}, \mathrm{Sr}$, $\mathrm{Co}, \mathrm{Na}$ and $\mathrm{Zn}$ in the light grey ash. However, in explaining these differences, one cannot rule out the effect of the postdepositional chemical processes and their different duration (Pierce et al., 1998).

The thickness of the humus horizon $(\mathrm{A}+\mathrm{AB})$ of the newly formed soil was defined using the data from two sections: the average values in sections A1/3 and S1/1 amounted to 467 and $468 \mathrm{~mm}$ correspondingly. The soil age established using the method of pedogenetic chronology (Lisetskii et al., 2016) appeared to be c. 2.9 ka. Hence its formation must have started in the second half of the 10th century BC, what in the northern Black Sea area corresponds to the Belozerka stage of the late Bronze Age.

The chemical composition of parent materials of the Crimean soils was investigated in Lisetskii and Ergina (2010). In parts of the region where ashy deposits cover larger areas, they can also be considered a soil 
Table 3

Chemical properties of soils formed on ash (S) and ash (A) from the cultural layers of archaeological sites of North-West Crimea.

\begin{tabular}{|c|c|c|c|c|c|c|c|c|c|c|c|}
\hline \multirow[t]{2}{*}{ Sample No. ${ }^{\text {a }}$} & \multirow[t]{2}{*}{ Depth, cm } & \multicolumn{2}{|c|}{ Munsell colour } & \multirow{2}{*}{$\begin{array}{l}\mathrm{pH} \\
\left(\mathrm{H}_{2} \mathrm{O}\right)\end{array}$} & \multirow[t]{2}{*}{ Corg, \% } & \multirow{2}{*}{$\begin{array}{l}\mathrm{CaCO}_{3}, \\
\%\end{array}$} & \multirow{2}{*}{$\begin{array}{l}\mathrm{P}_{2} \mathrm{O}_{5} \\
\mathrm{mg} \cdot \mathrm{kg}^{-1}\end{array}$} & \multirow{2}{*}{$\begin{array}{l}\mathrm{K}_{2} \mathrm{O} \\
\mathrm{mg} \cdot \mathrm{kg}^{-1}\end{array}$} & \multicolumn{3}{|c|}{$\mathrm{CEC}, \mathrm{cmol}^{+} \cdot \mathrm{kg}^{-1}$} \\
\hline & & Dry & Moist & & & & & & $\mathrm{Ca}^{2+}$ & $\mathrm{Mg}^{2+}$ & $\mathrm{Na}^{+}$ \\
\hline \multirow[t]{3}{*}{$\mathrm{S} 1 / 1$} & $0-18$ & 10 YR 5/2 & 10 YR $3 / 3$ & 8.2 & 4.86 & 9.1 & 10.4 & 45.5 & 24.4 & 2.5 & 0.5 \\
\hline & $18-50$ & 10 YR $6 / 2$ & 10 YR $3 / 2$ & 8.2 & 3.76 & 12.8 & 13.9 & 61.0 & 21.6 & 1.7 & 0.7 \\
\hline & $>50$ & 10 YR $7 / 2$ & 10 YR $5 / 4$ & 8.0 & 2.55 & 25.7 & 8.2 & 951.7 & 22.2 & 5.2 & 0.1 \\
\hline \multirow[t]{2}{*}{$\mathrm{A} 2 / 1$} & $0-19$ & 10 YR 5/2 & 10 YR $2 / 2$ & 7.9 & 5.27 & 34.7 & 22.6 & 21.1 & 23.3 & 6.0 & 0.5 \\
\hline & $19-38$ & 10 YR $5 / 1$ & 10 YR $3 / 2$ & 8.1 & 4.11 & 18.9 & 27.8 & 154.7 & 21.4 & 5.4 & 0.6 \\
\hline $\mathrm{S} 4 / 1$ & $0-22$ & 10 YR $6 / 2$ & 10 YR $3 / 3$ & 8.9 & 2.83 & 37.5 & 16.7 & 101.5 & 9.6 & 3.0 & 1.30 \\
\hline \multirow[t]{2}{*}{ S6 } & $0-16$ & 10 YR 6/1.5 & 10 YR $3 / 2$ & 9.1 & 3.29 & 44.0 & 1.5 & 36.7 & 16.2 & 8.9 & 0.5 \\
\hline & $16-28$ & 10 YR 6/2 & $10 \mathrm{YR} 4 / 3$ & 9.5 & 2.59 & 54.0 & 1.2 & 42.7 & 19.8 & 4.4 & 1.6 \\
\hline $\mathrm{A} 3 / 1$ & 235 & 10 YR $7 / 1$ & 10 YR $5 / 2$ & 7.4 & 0.84 & 17.0 & 0.8 & 5.1 & - & - & - \\
\hline $\mathrm{A} 3 / 2$ & 200 & 10 YR $6 / 2$ & 10 YR $5 / 3$ & 7.3 & 0.70 & 16.2 & 1.1 & 9.6 & - & - & - \\
\hline Mean (S) & - & - & - & 8.5 & 3.70 & 29.6 & 12.8 & 93.5 & 19.8 & 4.6 & 0.7 \\
\hline Mean (A) & - & - & - & 7.3 & 0.77 & 16.6 & 1.0 & 7.3 & - & - & - \\
\hline Chernozem $^{\mathrm{b}}$ & & & & $\begin{array}{l}6.8- \\
7.4\end{array}$ & $1.5-2.1$ & $17-28$ & 0.15 & $2-4$ & $23.4-37.2$ & $2.2-7.6$ & $\begin{array}{l}0.3- \\
1.6\end{array}$ \\
\hline
\end{tabular}

Note.

a Sample numbers correspond to those in Table 1.

b The analytical data for the background Chernozems $(0-20 \mathrm{~cm})$ in the study area are after Kogel', 1969.

parent material. The comparison of the composition of the two predominant types of parent material, the carbonate loams and limestone eluvium, with that of the ash of archaeological sites and of the soils formed on ash showed significant differences. The ash proved to have a higher (by more than 30\%) content of $\mathrm{P}, \mathrm{Ca}$ and $\mathrm{Sr}$ (as compared to loams), and of $\mathrm{P}, \mathrm{Co}, \mathrm{Sr}, \mathrm{Zn}, \mathrm{Pb}$ and $\mathrm{Cu}$ (as compared to eluvium). Moreover, ash contains a smaller proportion of $\mathrm{Cu}, \mathrm{Pb}, \mathrm{Fe}$ and $\mathrm{Ni}$ (as compared to loams), and of $\mathrm{Ca}$ (as compared to eluvium). For the soils formed on ash, regardless of the time of leaching, a decrease (as compared to ash) in the concentrations of $\mathrm{Ca}>\mathrm{Sr}>\mathrm{Mg}>\mathrm{P}$ was observed.

Along with the combustion temperature and the post-depositional processes, the chemical composition of ash may be influenced by some inclusions such as, for example, limestone and especially bones. The ash of the late Scythian hearth (A3/3) differed from all other samples (Table 1), not only in colour (10 YR 6/4) but also, as will be shown below, in chemical composition. As heating and cooking activities usually result in complete consumption of fuel, it should not be surprising that all examined ash samples proved to contain no trace of charcoal.

A cluster analysis by the 12 most diagnostic chemical elements has demonstrated typological differences between ash and the soils formed on it. Comparing the chemistry of the soils and ash of archaeological sites of north-western and piedmont Crimea shows certain regional differences in how the elemental composition of ash is transformed by pedogenesis. At the same time, despite the considerable differences in precipitation, the loss of sesquioxides in the soils of these regions (as compared to ash) is identical, amounting to c. $140 \%$.

The comparison of ash from two forest regions (Crimean piedmonts and the continental forest-steppe) by 22 chemical elements (Table 4) has demonstrated that only two of these elements had a comparable concentration with the difference not exceeding 10 percent. This suggests that the ancient population of these regions must have been using completely different types of fuel. Ash with a high concentration of animal bones, as it was at the Scythian settlement of Borisovka, is distinguished, among other things, by a high phosphorus content. While Horizon A $(0-25 \mathrm{~cm})$ of this region's background soils contains $0.21-0.35 \%$ of total phosphorus and has an average degree of supply of mobile phosphates $\left(\mathrm{P}_{2} \mathrm{O}_{5}\right.$ is $1.7 \mathrm{mg} \mathrm{kg}^{-1}$ ) (Lukin et al., 2000), the ash from the depth of $62-72 \mathrm{~cm}$ contained $0.95 \%$ of total phosphorus. As compared to the Crimean ash, the fossil ash of the continental forest-steppe shows lower content of $\mathrm{K}, \mathrm{As}, \mathrm{Al}, \mathrm{Cu}, \mathrm{Ca}, \mathrm{V}$ and $\mathrm{Si}$, while the concentration of the 13 other elements is higher.

Fourteen samples of fossil ash from all three investigated regions were subjected to the cluster analysis by 18 chemical elements (Fig. 4);
Table 4

Chemical composition of ash from cultural strata of the Scythian settlements: A167 - Borut-Khane, Piedmont Crimea; A16 - Borisovka, forest-steppe zone.

\begin{tabular}{|c|c|c|c|}
\hline \multirow[t]{2}{*}{ Chemical elements } & A167 & A16 & Percentage of differences: \\
\hline & $63-73 \mathrm{~cm}$ & $62-72 \mathrm{~cm}$ & $100 *[(\mathrm{~A} 167 / \mathrm{A} 16)-1]$ \\
\hline
\end{tabular}

\begin{tabular}{|c|c|c|c|}
\hline \multicolumn{4}{|c|}{$\begin{array}{l}\text { Accumulated elements in the ash of the Crimean piedmonts as compared to the ash of } \\
\text { the continental forest-steppe }\end{array}$} \\
\hline $\mathrm{K}$ & 1.62 & 0.91 & +78.0 \\
\hline As & 4.66 & 2.78 & +67.6 \\
\hline $\mathrm{Al}$ & 4.00 & 2.39 & +67.4 \\
\hline $\mathrm{Cu}$ & 19.22 & 12.70 & +51.3 \\
\hline $\mathrm{Ca}$ & 12.66 & 8.39 & +50.9 \\
\hline $\mathrm{V}$ & 63.80 & 48.52 & +31.5 \\
\hline $\mathrm{Si}$ & 16.75 & 14.97 & +11.9 \\
\hline \multicolumn{4}{|c|}{$\begin{array}{l}\text { Dispersed elements in the ash of the Crimean piedmonts as compared to the ash of the } \\
\text { continental forest-steppe }\end{array}$} \\
\hline $\mathrm{Zr}$ & 161.99 & 444.15 & -63.5 \\
\hline $\mathrm{Sr}$ & 304.39 & 783.79 & -61.2 \\
\hline $\mathrm{Mn}$ & 0.07 & 0.16 & -56.3 \\
\hline $\mathrm{Zn}$ & 133.22 & 272.84 & -51.2 \\
\hline $\mathrm{Pb}$ & 16.07 & 27.37 & -41.3 \\
\hline $\mathrm{P}_{2} \mathrm{O}_{5}$ & 0.61 & 0.95 & -35.8 \\
\hline Co & 10.42 & 15.76 & -33.9 \\
\hline $\mathrm{Na}$ & 2.03 & 2.81 & -27.8 \\
\hline $\mathrm{Ba}$ & 505.56 & 692.97 & -27.0 \\
\hline $\mathrm{Ti}$ & 0.27 & 0.36 & -25.0 \\
\hline $\mathrm{Ni}$ & 36.65 & 44.98 & -18.5 \\
\hline $\mathrm{Cr}$ & 73.04 & 88.94 & -17.9 \\
\hline $\mathrm{Fe}$ & 2.18 & 2.51 & -13.1 \\
\hline \multicolumn{4}{|c|}{ Concentrations with a difference of no more than $10 \%$} \\
\hline $\mathrm{Rb}$ & 62.21 & 68.32 & -8.9 \\
\hline $\mathrm{Mg}$ & 1.37 & 1.37 & 0.0 \\
\hline
\end{tabular}

the insignificantly variable elements with the variation coefficient of $\leq 14 \%$ (Ti, Fe, Mg and $\mathrm{Rb}$ ) were excluded from calculations. Judging by the threshold distance (D), two close objects, A1 and A2, and two other groups of ash that differ significantly in their chemical composition could be identified.

The comparison of the average chemical element content in the objects and groups (Table 5) has shown that, judging by the quantity of extremes (maxima and minima), sample A1 (ash from the forest-steppe settlement of Borisovka) is the most distinct.

\subsection{Geochemical transformation of ash by pedogenesis and the dating of ash deposits}

Combustion of plant-based fuels produces calcite, potash and other carbonates (Aleksandrovskii, 2007). The study of the chemical 


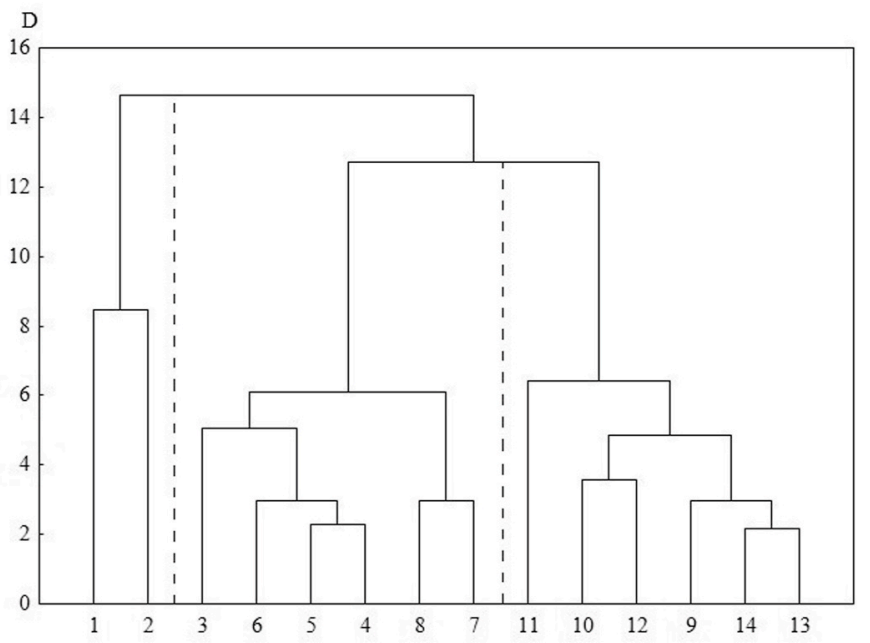

Fig. 4. Dendrogram of the ash sample distribution (A) according to $18 \mathrm{chem}$ ical elements (macroelements ( $\mathrm{Ca}, \mathrm{Si}, \mathrm{Al}, \mathrm{Mn}, \mathrm{P}, \mathrm{K}, \mathrm{Na})$ and trace elements (V, $\mathrm{Cr}, \mathrm{Ni}, \mathrm{Co}, \mathrm{Cu}, \mathrm{Zn}, \mathrm{As}, \mathrm{Sr}, \mathrm{Pb}, \mathrm{Ba}, \mathrm{Zr}$ )). Key to the figure: 1 - A16; 2 - S1/1 (>50 $\mathrm{cm}) ; 3$ - A2/2; 4 - A1/3 (60-70 cm); 5 - A1/3 (80-90 cm); 6 - S1/2 (56-61 $\mathrm{cm}) ; 7$ - A3/1; 8 - A3/3; 9 - A7 (>37 cm); $10-\mathrm{A} 8$ (>33.5 cm); $11-\mathrm{A} 9$ (>32 $\mathrm{cm}) ; 12$ - A2/1 (39-41 cm); 13 - A167 $(63-73 \mathrm{~cm}) ; 14-\mathrm{A} 10(>30 \mathrm{~cm})$.

Table 5

Colour and chemical composition of ash in the groups identified by the cluster analysis.

\begin{tabular}{|c|c|c|c|c|c|}
\hline Indicator & Units & $\mathrm{A} 1$ & A2 & Group 1 & Group 2 \\
\hline Colour & - & $10 \mathrm{YR}$ & $10 \mathrm{YR}$ & $10 \mathrm{YR} 7 / 1$ to & $10 \mathrm{YR} 7 / 1$ to \\
\hline $\begin{array}{l}\text { (Munsell; } \\
\text { dry) }\end{array}$ & & $6 / 2$ & $7 / 2$ & 10 YR $6 / 2$ & 10 YR 5/1.5 \\
\hline $\mathrm{CaO}$ & $\%$ & 11.7 & 13.7 & 12.5 & 17.9 \\
\hline $\mathrm{MnO}$ & $\%$ & 0.2 & 0.1 & 0.1 & 0.1 \\
\hline $\mathrm{SiO}_{2}$ & $\%$ & 32.1 & 33.9 & 50.5 & 35.0 \\
\hline $\mathrm{P}_{2} \mathrm{O}_{5}$ & $\%$ & 2.2 & 0.7 & 0.6 & 1.2 \\
\hline $\mathrm{K}_{2} \mathrm{O}$ & $\%$ & 1.1 & 1.5 & 1.9 & 1.8 \\
\hline $\mathrm{Na}_{2} \mathrm{O}$ & $\%$ & 2.8 & 2.9 & 1.6 & 2.2 \\
\hline $\mathrm{Al}_{2} \mathrm{O}_{3}$ & $\%$ & 4.5 & 6.1 & 9.5 & 7.2 \\
\hline $\mathrm{Sr}$ & $\begin{array}{l}\mathrm{mg} \\
\mathrm{kg}^{-1}\end{array}$ & 783.8 & 431.6 & 329.2 & 349.4 \\
\hline $\mathrm{Zn}$ & $\begin{array}{l}\mathrm{mg} \\
\mathrm{kg}^{-1}\end{array}$ & 272.8 & 157.7 & 89.8 & 132.3 \\
\hline Co & $\begin{array}{l}\mathrm{mg} \\
\mathrm{kg}^{-1}\end{array}$ & 15.8 & 34.2 & 16.8 & 16.1 \\
\hline $\mathrm{Pb}$ & $\begin{array}{l}\mathrm{mg} \\
\mathrm{kg}^{-1}\end{array}$ & 27.4 & 35.0 & 13.3 & 19.3 \\
\hline $\mathrm{Zr}$ & $\begin{array}{l}\mathrm{mg} \\
\mathrm{kg}^{-1}\end{array}$ & 444.2 & 281.7 & 239.5 & 169.3 \\
\hline $\mathrm{Cu}$ & $\begin{array}{l}\mathrm{mg} \\
\mathrm{kg}^{-1}\end{array}$ & 12.7 & 23.9 & 38.3 & 20.3 \\
\hline As & $\begin{array}{l}\mathrm{mg} \\
\mathrm{kg}^{-1}\end{array}$ & 2.8 & 5.3 & 5.7 & 5.2 \\
\hline V & $\begin{array}{l}\mathrm{mg} \\
\mathrm{kg}^{-1}\end{array}$ & 48.5 & 86.7 & 64.5 & 66.2 \\
\hline $\mathrm{Ba}$ & $\begin{array}{l}\mathrm{mg} \\
\mathrm{kg}^{-1}\end{array}$ & 693.0 & 611.7 & 482.0 & 455.5 \\
\hline $\mathrm{Ni}$ & $\begin{array}{l}\mathrm{mg} \\
\mathrm{kg}^{-1}\end{array}$ & 45.0 & 53.9 & 46.2 & 38.7 \\
\hline $\mathrm{Cr}$ & $\begin{array}{l}\mathrm{mg} \\
\mathrm{kg}^{-1}\end{array}$ & 88.9 & 108.3 & 80.5 & 84.7 \\
\hline
\end{tabular}

composition of the soils and ash at four archaeological sites in our study region 2 (Piedmont Crimea) has demonstrated that in the course of pedogenesis, the soils (as compared to ash) accumulate $\mathrm{Cu}, \mathrm{As}, \mathrm{Pb}$ and $\mathrm{SiO}_{2}$, while losing $\mathrm{Sr}, \mathrm{Ca}, \mathrm{Mg}, \mathrm{P}_{2} \mathrm{O}_{5}$ and $\mathrm{K}_{2} \mathrm{O}$. As shown in Lisetskii et al., 2016), in the conditions of regional pedogenesis, $\mathrm{Cu}$ and $\mathrm{Pb}$, which are actively accumulated by plants, accumulate in the soil in higher concentrations than in parental rocks (loams and limestone eluvium).
As compared to the buried ash, the soils formed on ash have a higher content of organic carbon, labile phosphorus and potassium, with the solution reaction changing from alkalescent to strongly alkaline. This demonstrates a considerable transformation of ash in the process of pedogenesis.

A method for calculating the soil formation rate was proposed in Alexander (1986) and is based on the ratio of the concentration of elements in the soil and in the weathered rock, respectively. After 17-19 centuries of pedogenesis, the soils of the piedmont Crimea become, on average (judging by the value of $\left.\mathrm{SiO}_{2} /\left(\mathrm{RO}+\mathrm{R}_{2} \mathrm{O}\right)\right), 36 \%$ less alkaline as compared to the initial state of the ash of which they were formed. In contrast to the underlying ashy stratum, which is insignificantly affected by the pedogenesis, the overlying $35-37 \mathrm{~cm}$ thick layer of soil shows higher concentration of $\mathrm{Cu}>\mathrm{As}>\mathrm{SiO}_{2}>\mathrm{Al}_{2} \mathrm{O}_{3}>\mathrm{Pb}$ (in the ranged sequence), whereas the concentration of $\mathrm{Sr}, \mathrm{Ca}, \mathrm{Co}, \mathrm{Mg}$ and $\mathrm{Na}_{2} \mathrm{O}$ decreases. Based on these elements, and using the formula (2), we rated the duration of the pedogenetic transformation of the ash ( $\mathrm{T}$, years). For the sites of Ak-Kaya, Kermen-Kyr and Zayachye Vostochnoye, which are of similar age, Formula (2) gives close values of T (1.73-1.84), whereas for the ash of Borut-Khane (sample from the depth of $63-73 \mathrm{~cm}$ ) T equals 2.23. The close $T$ values for the newly formed soils at these three sites indicate a practically synchronous beginning of the pedogenetic transformation of their ashy deposits. The fact that life at these settlements stopped simultaneously in the 3rd century $\mathrm{AD}$ is also confirmed archaeologically. At the same time, the soils of the Borut-Khane settlement which, judging by the pottery from the ashy mound, has a narrower chronology (1st century $\mathrm{BC}-1$ st century $\mathrm{AD}$ ), prove to be more leached, which implies a longer period of pedogenesis. Calculations of differences on the basis of the $\mathrm{T}$ values suggest that the formation of the new soil on the ashy deposits of Borut-Khane began in the early 1st century AD.

Hence, stable associations of chemical elements, indicating the processes of accumulation and leaching in the soils formed on ashy deposits of archaeological sites, make it possible to date the end of occupation at these sites.

\subsection{Properties of ash of different geneses}

Out of the 28 ash samples produced from different sorts of potential fuel, $18(64 \%)$ were close in colour to the ash of archaeological sites where light grey (10 YR 7/1 and 7/2) and light brownish grey (10 YR 6/ 2) hues predominate (Table 1). Less often, the experimental ash shows dark grey and very dark grey colour (10 YR 4/1 and 3/1), and only rarely (willow and reed) is it black (7.5 YR 2/0, 2.5 YR 2.5/0).

Out of the examined fuel types, the most distinctive prove to be the Crimean wormwood (by $\mathrm{Cu}, \mathrm{Mn}$, As and Co), horse dung (by $\mathrm{Pb}$, As, Co and $\mathrm{Mn}$ ) and cow dung (by Mo and Mn). As can be seen in Fig. 5, in terms of their chemical composition, the ash of Borut-Khane (A167) and the experimental ash of dung and plant-based fuels that constitute Group 2, as well as samples from Group 1 (wood of small-leaved species such as willow and poplar), which have similar properties, form a separate cluster with high values of the threshold distance (D).

The other groups, which include ashes of both arboreal and gramineous plants (Groups 3-7 in Fig. 5) differ markedly in their chemical composition from both the dung ash (P19, P20) and the ash of Borut-Khane (A167).

An integral evaluation of the properties of the plants and other organic substances using the PP indicator (plant properties) shows (Table 6) that samples of Group 2 (horse and cattle dung, pine, wormwood and southern saltwort (P2)) demonstrate the closest similarity with the ash of Borut-Khane (A167).

In agreement with other works (Etiégni and Campbell, 1991; Aleksandrovskii, 2007), the comparative analysis of ash from different sources has shown that different kinds of wood, as well as gramineous plants and straw differ significantly in their chemical composition from the dung ash. This makes it possible to use the concentrations of $\mathrm{Zn}, \mathrm{Cu}$, 




$\begin{array}{lllllllllllllllllllllllll}17 & 16 \mathrm{~A} 16719 & 20 & 25 & 8 & 2 & 23 & 22 & 7 & 15 & 6 & 26 & 24 & 13 & 4 & 14 & 21 & 18 & 11 & 10 & 9 & 5 & 3 & 12 & 1\end{array}$

Fig. 5. Cluster analysis of samples of the plant and dung ash (numbers correspond to those in Table 2).

$\mathrm{Mn}, \mathrm{Cd}, \mathrm{Pb}, \mathrm{As}, \mathrm{Hg}$, Mo and $\mathrm{Co}$, along with other techniques, such as the study of phytoliths and dung spherulites, to identify ash of different geneses in archaeological contexts.

\subsection{Different types of fuel and their indications in the composition of ash}

The elemental composition of the ash produced from grasses that largely determine the composition of dung on pastures was compared with that of the ash produced from the fossil oak wood of the mid-4th century BC (Table 2, sample P22). This comparison showed significant differences between oak wood and steppe hay in chemical elements and oxides. Only in the amount of $\mathrm{Cr}$ and $\mathrm{Ti}$, the values obtained were close. By contrast, the concentrations of As and Ca for wood, and, predictably, of silicon dioxide $\left(\mathrm{SiO}_{2}\right)$ for grasses appear as indicators of the differences.

Taking into account those 13 elements whose content in the ash from the Borisovka settlement was higher than in the ash of Borut-Khane (Table 1), the oak ash (P22) demonstrated a higher concentration of $\mathrm{Sr}, \mathrm{Na}, \mathrm{Zr}, \mathrm{Fe}$ and $\mathrm{Ba}$, as compared to that of grasses (P28). Possibly, this can be explained by the fact that other species of tree beside oak were used for fuel by the dwellers of Borisovka.

Having evaluated the relative differences between the objects, using the formula 100·[(X/Y)-1], the data in Table 6 makes it possible to arrive at the following conclusions: 1) the wood ash and the dung ash have the maximum differences; 2) the elemental composition of the oak ash and the ash of the Borut-Khane settlement differ fundamentally; in the wood ash, the concentration of eight elements is lower, showing similar values only for $\mathrm{Cd} ; 3$ ) despite certain differences, the ash from Borut-Khane is close to the horse and cow dung, being a bit closer to the former.

Table 6

Chemical composition of the plant and dung ash in samples $\left(\mathrm{P}, \mathrm{mg} \mathrm{kg}^{-1}\right)$ and their quality (PP).

\begin{tabular}{|c|c|c|c|c|c|c|c|c|c|c|c|}
\hline Group $^{a}$ & PNo & $\mathrm{Zn}$ & $\mathrm{Cu}$ & $\mathrm{Mn}$ & $\mathrm{Cd}$ & $\mathrm{Pb}$ & As & $\mathrm{Hg}(\mathrm{n} \cdot 1000)$ & Mo & Co & $\mathrm{PP}^{\mathrm{b}}$ \\
\hline \multirow[t]{6}{*}{2} & 19 & 162.7 & 41.5 & 544.7 & 0.7 & 12.6 & 2.93 & 2.3 & 5.8 & 3.3 & 5.47 \\
\hline & 20 & 155.3 & 30.3 & 935.5 & 1.5 & 20.9 & 2.91 & 2.2 & 3.9 & 3.6 & \\
\hline & 25 & 200.9 & 20.0 & 423.4 & 0.6 & 6.5 & 1.86 & $<$ LOD & 1.7 & 4.2 & \\
\hline & 8 & 144.5 & 76.2 & 480.0 & 0.6 & 10.9 & 4.68 & 3.8 & 2.8 & 4.4 & \\
\hline & 2 & 164.4 & 46.1 & 218.1 & 0.4 & 12.4 & 3.79 & 4.0 & 5.4 & 2.1 & \\
\hline & $\bar{X}$ & 165.6 & 42.8 & 520.3 & 0.8 & 12.7 & 3.20 & 2.5 & 3.9 & 3.5 & \\
\hline \multirow[t]{7}{*}{6} & 14 & 65.8 & 24.1 & 147.2 & 0.7 & 10.2 & 0.94 & 3.4 & 1.6 & 1.0 & 2.72 \\
\hline & 21 & 45.5 & 39.7 & 252.2 & 0.8 & 5.9 & 1.13 & 3.7 & 1.6 & 1.4 & \\
\hline & 18 & 69.4 & 22.2 & 45.2 & 0.5 & 13.7 & 0.32 & 1.9 & 3.3 & 0.5 & \\
\hline & 11 & 67.6 & 22.5 & 113.0 & 0.3 & 10.2 & 1.42 & 3.6 & 1.8 & 1.1 & \\
\hline & 10 & 64.3 & 22.9 & 94.2 & 0.3 & 8.4 & 1.22 & 2.1 & 1.5 & 1.1 & \\
\hline & 9 & 102.7 & 25.7 & 117.4 & 0.7 & 7.6 & 0.90 & 5.6 & 0.8 & 1.4 & \\
\hline & $\bar{X}$ & 69.2 & 26.2 & 128.2 & 0.5 & 9.3 & 1.00 & 3.4 & 1.7 & 1.1 & \\
\hline \multirow[t]{3}{*}{1} & 16 & 210.2 & 30.1 & 74.9 & 2.4 & 14.8 & 0.49 & 1.4 & 0.7 & 0.9 & 2.69 \\
\hline & 17 & 204.0 & 46.6 & 87.9 & 1.9 & 14.3 & 0.50 & 1.8 & 0.7 & 1.1 & \\
\hline & $\bar{X}$ & 207.1 & 38.3 & 81.4 & 2.1 & 14.6 & 0.50 & 1.6 & 0.7 & 1.0 & \\
\hline \multirow[t]{5}{*}{7} & 5 & 143.0 & 33.5 & 114.0 & 0.2 & 5.9 & 0.93 & 2.6 & 1.7 & 1.2 & 2.40 \\
\hline & 3 & 164.6 & 36.9 & 126.5 & 0.1 & 4.4 & 1.23 & $<$ LOD & 2.6 & 1.0 & \\
\hline & 12 & 121.3 & 29.9 & 150.0 & 0.2 & 3.0 & 1.01 & 2.7 & 1.3 & 1.4 & \\
\hline & 1 & 115.2 & 34.3 & 59.9 & 0.2 & 7.0 & 0.88 & 4.2 & 1.4 & 0.8 & \\
\hline & $\bar{X}$ & 136.0 & 33.7 & 112.6 & 0.2 & 5.0 & 1.00 & 2.4 & 1.7 & 1.1 & \\
\hline \multirow[t]{3}{*}{4} & 26 & 35.6 & 9.8 & 204.8 & 0.2 & 1.0 & 0.97 & 4.7 & 2.2 & 1.1 & 1.70 \\
\hline & 24 & 44.9 & 11.9 & 279.4 & 0.2 & 1.1 & 1.37 & 4.0 & 2.7 & 1.2 & \\
\hline & $\bar{X}$ & 40.3 & 10.8 & 242.1 & 0.2 & 1.0 & 1.20 & 4.3 & 2.5 & 1.1 & \\
\hline \multirow[t]{6}{*}{3} & 23 & 60.0 & 14.4 & 104.0 & 0.4 & 4.8 & 0.24 & 2.6 & 0.9 & 0.6 & 1.58 \\
\hline & 22 & 22.6 & 22.3 & 106.5 & 0.3 & 4.3 & 0.14 & 2.8 & 1.2 & 1.2 & \\
\hline & 7 & 100.4 & 20.5 & 57.1 & 0.3 & 2.7 & 0.32 & 2.1 & 0.9 & 0.4 & \\
\hline & 15 & 64.3 & 13.3 & 30.4 & 0.8 & 4.8 & 0.27 & 1.9 & 0.9 & 0.3 & \\
\hline & 6 & 54.4 & 9.8 & 47.6 & 0.1 & 4.7 & 0.29 & 2.2 & 0.7 & 0.5 & \\
\hline & $\bar{X}$ & 60.4 & 16.1 & 69.1 & 0.4 & 4.3 & 0.30 & 2.3 & 0.9 & 0.6 & \\
\hline \multirow[t]{3}{*}{5} & 13 & 23.7 & 10.8 & 38.0 & 0.2 & 3.4 & 0.95 & 7.3 & 0.7 & 0.5 & 1.36 \\
\hline & 4 & 33.7 & 11.9 & 56.5 & 0.2 & 4.9 & 1.01 & 8.9 & 0.8 & 0.6 & \\
\hline & $\bar{X}$ & 28.7 & 11.4 & 47.2 & 0.2 & 4.2 & 1.00 & 8.1 & 0.7 & 0.5 & \\
\hline Ash deposit & A167 & 59.3 & 27.0 & 428.8 & 0.3 & 9.3 & 5.20 & 38.7 & 1.5 & 4.5 & 5.18 \\
\hline
\end{tabular}

Note.

a The sequence of groups in the table follows the PP indicator.

${ }^{\mathrm{b}}$ Calculation of the PP indicator has been made according to the formula of geometric mean: $\mathrm{PP}=\left(\mathrm{x}_{1} \cdot \mathrm{x}_{2} \cdot \ldots \cdot \mathrm{x}_{9}\right)^{1 / 9}$, where $\mathrm{x}_{1}, \mathrm{x}_{2} \ldots \mathrm{x}_{9}$ is the content of chemical elements; LOD - limit of detection. 
Given the chemical composition of the ash from the late Scythian settlements of piedmont Crimea, the 25 wood and plant species studied by us (Table 2) are very unlikely to have been used there as the main fuel. The closest relationship to the Borut-Khane ash is demonstrated by Group 2 in Table 6 (horse and cow dung, Crimean pine, Crimean wormwood and southern saltwort). For the ignition of dung, the easily available stalks of wormwood and saltwort, as well as pine twigs, could have been used too. Unlike the other six clusters (Fig. 5), Group 2 features higher concentrations of $\mathrm{Mn}, \mathrm{Cu}, \mathrm{As}, \mathrm{Mo}$ and $\mathrm{Co}$. The closeness relation (r) between ash A167 and the average content of the nine chemical elements is 0.987 , which means that the contribution of this group to the ash deposits of Borut-Khane has amounted to $97 \%$.

In its chemical composition, the ash from the Scythian settlement of Borut-Khane is closest to the horse dung, essential differences emerging only in the quantity of Mo. Certain similarities can also be observed with the pine ash, except for $\mathrm{Zn}$ and As. At the same time, it differs significantly, in five elements out of nine, from cow dung.

\subsection{Geochemical indicators of ash of different geneses}

The analysis of relative differences was conducted using the ensemble of chemical elements ( $\mathrm{P}, \mathrm{K}, \mathrm{Mn}, \mathrm{Zn}, \mathrm{Co}, \mathrm{Pb}, \mathrm{Sr}$ and $\mathrm{Zr}$ ) that best characterise the differences between the wood ash and dung ash. Using the formula $100 *[(\mathrm{~A} / \mathrm{B}(\mathrm{C}))-1]$, where $\mathrm{A}, \mathrm{B}$ and $\mathrm{C}$ are samples $\mathrm{S} 1 / 2, \mathrm{~A} 16$ and $\mathrm{A} 167$ respectively, the following summary estimate of differences was obtained: A and B: -52 , A and C: +443 . Hence, it can be assumed that the ash of colour 10 YR $7 / 2$ is primarily a product of wood combustion (Type 1). Employing the same formula $100 *[(A / B(C))-1]$, where A, B and C are samples A1/3, A16 and A167 respectively, a similar calculation was made to estimate the differences between the light brownish grey ash $(\mathrm{A} 1 / 2)$ and the ash deriving from wood and dung. In this case, the summary estimate of differences was as follows: A and B: -301, A and C: 45 . This suggests that this variety of ash (central cluster [from A3 to A7] in Fig. 4) is likely to result from the combustion of kizyak with a significant addition of wood, i.e. what may be called a mixed type of ash (Type 2). Despite certain differences in the chemical composition, the ash of all late Scythian settlements and the ash of the Greek farmhouse of Kunan (burnt roof of felt and straw) can be ascribed to Type 3, with the animal components prevailing over the plant-based (Group 2 in Table 5). This type can be interpreted as dung (kizyak).

Comparison of objects A1 (A16) (pale brown ash) and A2 (S1/1) (light grey ash) in terms of relative (\%) differences in the content of 22 chemical elements, using the criterion of differences $> \pm 50 \%$, has demonstrated that $\mathrm{A} 1$ has a twice as high content of bulk phosphorus and higher concentrations in the group $\mathrm{Sr}>\mathrm{Zn}>\mathrm{Mn}>\mathrm{Zr}$, while the amount of cobalt is lower. With regard to the remaining 16 elements, the differences were small. This fact suggests that at multiperiod settlement S11-022 (S1/2), along with wood (perhaps not only oak), other fuels were also used. However, when A1 is compared to the ash from piedmont Crimea (A13 $=\mathrm{A} 167$, Borut-Khane), relative differences of $>50 \%$ occur on the basis of a completely different (except Sr) ensemble of elements: $\mathrm{Sr}>\mathrm{Co}>\mathrm{Ca}>\mathrm{Pb}>\mathrm{Na}$. Thus, the chemical signature of wood ash and of that of mixed fuels differs significantly from the ash resulting from the combustion of dung.

The distribution of geochemical properties in objects of Group 1 (Table 5) suggests ash of mixed origin, by contrast to Group 2, which primarily characterizes dung ash. Taking object A1 and Group 2 (A13) as typical examples of wood and dung ash respectively, and considering their relative (\%) differences in the content of 22 chemical elements, a set of elements diagnostic of these two kinds of fuel was identified. In a ranged sequence, these elements appear as follows: $\mathrm{Zr}>\mathrm{Mn}>\mathrm{Sr}>\mathrm{Zn}>$ $\mathrm{P}_{2} \mathrm{O}_{5}>\mathrm{Pb}$. A higher concentration of these six elements, and in this order, distinguishes wood ash from the ash deriving from dung.

\section{Conclusion}

In the south of the East European Plain, where the cold period amounts from $34 \%$ to $50 \%$ of a calendar year, there was a constant need of fuel for both cooking and heating. This explains the wide distribution of ashy soils and massive ashy deposits in this region of long and intensive human activities. On the arable lands of Plain Crimea alone, they cover an area of 14,200 ha. From the Bronze Age to the sub-modern period, in the steppes of the northern Black Sea region, kizyak, a mixture of dung and straw, was the main fuel. In the conditions of the East European Plain, the assemblage of chemical elements $\mathrm{Zr}, \mathrm{Mn}, \mathrm{Sr}, \mathrm{Zn}, \mathrm{P}_{2} \mathrm{O}_{5}$ and $\mathrm{Pb}$ proved to be diagnostic of ash of different geneses. Their diagnostic effectiveness has to be tested also in other regions of the world. The prevalence of dung fuel among the Scythian and Tatar population of the Crimean piedmonts in the 3rd century BC through the 19th century $\mathrm{AD}$ was an effect of not only the unavailability of firewood but also of the traditional mode of life with the changing, but ever-important, role of livestock breeding. Based on the ratio of the stable associations of chemical elements indicating the processes of accumulation $(\mathrm{Cu}, \mathrm{As}, \mathrm{Si}$, $\mathrm{Al}$ and $\mathrm{Pb}$ ) and leaching $(\mathrm{Sr}, \mathrm{Ca}, \mathrm{Co}, \mathrm{Mg}$ and $\mathrm{Na}$ ) in the soils of different age formed on ash, it is possible to establish the age of ashy deposits by determining the time at which they stopped to form.

\section{Declaration of competing interest}

The authors declare that they have no known competing financial interests or personal relationships that could have appeared to influence the work reported in this paper.

\section{Acknowledgements}

The authors wish to thank Tatyana Smekalova and Alexander Garipov for their support in the field and Sergey Lukin for his assistance with laboratory analyses at the Belgorod Agrochemical Service Centre, as well as two anonymous reviewers for their useful comments and suggestions.

\section{Appendix. ASupplementary data}

Supplementary data to this article can be found online at https://doi. org/10.1016/j.quaint.2020.11.030

\section{References}

Aleksandrovskii, A.L., 2007. Pyrogenic origin of carbonates: evidence from pedoarchaeological investigations. Eurasian Soil Sci. 40, 471-477.

Alexander, E.B., 1986. Rate of soil from bedrock or consolidated sediment. Phys. Geogr. 6, 26-42.

Arinushkina, E.V., 1970. Manual for the Chemical Analysis of Soils. University Press, Moscow.

Belozor, V.P., 2012 On ash deposits of the early Iron age. In: Suprunenko, O.B., et al (Eds.), Fenomen Bil's'kogo gorodišča. Kiev-Poltava, pp. 19-21.

Bibikova, V.I., 1970. Faunal remains from the settlement near the village of Kirov. In: Leskov, A.M. (Ed.), Drevnosti Vostočnogo Kryma (predskifskij period i skify). Naukova dumka, Kiev, pp. 97-112.

Braadbaart, F., Poole, I., Huisman, H.D.J., van Os, B., 2012. Fuel, fire and heat: an experimental approach to highlight the potential of studying ash and char remains from archaeological contexts. J. Archaeol. Sci. 39, 836-847.

Braadbaart, F., van Brussel, T., van Os, Eijskoot, B.Y., 2017. Fuel remains in archaeological contexts: experimental and archaeological evidence for recognizing remains in hearths used by Iron Age farmers who lived in peatlands. Holocene 27, $1682-1693$.

Brink, J., 2008. In: Imagining Head-Smashed-In: Aboriginal Buffalo Hunting on the Northern Plains. AU Press, Edmonton.

Canti, M.G., 2003. Aspects of the chemical and microscopic characteristics of plant ashes found in archaeological soils. Catena 54, 339-361.

Çelebi, E., 2008. Book of Travels. Crimea and Borderlands. Selections from the Book of an 17th-Century Ottoman Traveller. Dolja, Simferopol.

Čendev, Ju.G., Aleksandrovskij, A.L., Chochlova, O.S., Rusakov, A.V., Šapovalov, A.S. Borbukova, D.A., 2014. Soils of scythian hillforts in the southern forest-steppe of the central Russian Upland. In: Gubin, S.V., Borisov, A.V., Udalzov, S.N. (Eds.), 
Materialy Vserossijskoj naučnoj konferencii po archeologičeskomu počvovedeniju. Puscino, pp. 247-250.

Cordova, C.E., Lehman, P.H., 2003. Archaeolopalynology of synanthropic vegetation in the chora of Chersonesos, Crimea, Ukraine. J. Archaeol. Sci. 30, 1483-1501.

Courty, M.A., Golderg, P., Macphail, R., 1989. Soils and Micromorphology in Archaeology. Cambridge University Press, Cambridge.

Daszkiewicz, M., Schneider, G., 2011. Untersuchungen von Erdproben und Keramik. In: Sava, E., Kaiser, E. (Eds.), Die Siedlung mit Aschehügeln beim Dorf Odaia-Miciurin, Republik Moldova, Chișinău, pp. 398-414.

Demkin, V.A., 2011. Über die Entstehung von Aschehügeln auf Siedlungen der späten Bronzezeit aufgrund der Ergebnisse von bodenkundlichgeochemischen und mineralogischen Analysen. In: Sava, E., Kaiser, E. (Eds.), Die Siedlung mit Aschehügeln beim Dorf Odaia-Miciurin, Republik Moldova. Chișinău, pp. 526-532.

Dirin, A.A., 1896. Cape Zyuk and archaeological discoveries made there. Zapisk Odesskogo Obšcestva Istorii i Drevnostej 19, 121-131.

Etiégni, L., Campbell, A.G., 1991. Physical and chemical characteristics of wood ash. Biosource Technol. 37, 173-178.

Facklam, M., 2011. Bodenkundliche Untersuchungen. In: Sava, E., Kaiser, E. (Eds.), Die Siedlung mit Aschehügeln beim Dorf Odaia-Miciurin, Republik Moldova, Chișinău, pp. 367-377.

FAO, 1998. International Soil Reference and Information Center (ISRIC) and International Society of Soil Science (ISSS). World Reference Base for Soil Resources. FAO, Rome.

Garkusha, L. Ya, Bagrova, L.A., 2012. Composition, structure and modern environmenta state of "Dubki" at the forest-steppe belt of the Crimea mountains. Optim. Protect. Ecosyst. 6, 62-75.

Gershkovich, Ya.P., 2003. Farmers and pastoralists of the Pontic lowland during the Bronze Age. In: Levine, M., Renfrew, C., Boyle, K. (Eds.), Prehistoric Steppe Adaptation and the Horse. McDonald Institute for Archaeological Research, Cambridge, pp. 307-318.

Gerškovič, J.P., 1999. Studien zur spätbronzezeitlichen Sabatinovka-Kultur am unteren Dnepr und an der Westküste des Azov'schen Meeres (Archäologie in Eurasien 7). Rahden/Westf.

Gerškovič, J.P., 2004. The phenomenon of the Belogrudovka-type ash deposits. Rossijskaja Archeologija 4, 104-113.

Godley, A.D., 1920. Herodotus, with an English Translation by A. D. Godley. Harvard University Press, Cambridge.

Hannestad, L., 2007. Timber as a trade resource of the Black Sea. In: Gabrielsen, V., Lund, J. (Eds.), The Black Sea in Antiquity. Regional and Interregional Economic Exchanges. Aarhus University Press, Aarhus, pp. 85-99.

Hillis, W.E., 1987. Heartwood and Tree Exudates. Springer, New York.

Hort, A.F., 1916. Theophrastus. Enquiry into Plants. Volume I: Books 1-5. Harvard University Press, Cambridge, MA.

Kogel’, N.S. (Ed.), 1969. Soils of Crimea, Simferopol.

Kolotuchin, V.A., 1996. Mountain Crimea in the Late Bronze Age through the Early Iron Age. Južnogorodskie Vedomosti, Kiev.

Kolotuchin, V.A., 2003. The Late Bronze Age of Crimea. Stilos, Kiev.

Kovács, G., Kulcsár, G., Serlegi, G., Jaeger, M., Taylor, N., Petö, Á., 2017. Results of the soil micro-morphological analysis at Bronze Age archaeological site known as 'behind Kakucs-Turján'. Agrokém. Talajt. 66, 35-60.

Kovalčuk, A.V., 2015. Location of ash deposits at the settlements of the Karalar coast. In: Zin'ko, V.N. (Ed.), XVI Bosporskie čtenija. Bospor Kimmerijskij i varvarskij mir v period antičnosti i srednevekov'ja. Geografičeskaja sreda i socium. Kerch, pp. 189-196.

Kruglikova, I.T., 1975. Agriculture of the Bosporus. Nauka, Moscow.

Levkovskaja, G.M., 1970. The reconstruction of the paleogeographical conditions at the settlement of Chaika based on pollen data. Kratk. Soobshcheniya Inst. Arkheol. 124 $102-108$

Liodakis, S., Katsigiannis, G., Kakali, G., 2005. Ash properties of some dominant Greek forest species. Thermochim. Acta 437, 158-167.

Lisetskii, F.N., Ergina, E.I., 2010. Soil development on the Crimean Peninsula in the Late Holocene. Eurasian Soil Sci. 43, 601-613.

Lisetskii, F.N., Rodionova, M.E., 2015. Transformation of dry-steppe soils under longterm agrogenic impacts in the area of ancient Olbia. Eurasian Soil Sci. 48 (4), 347-358.

Lisetskii, F.N., Stolba, V.F., Goleusov, P.V., 2016. Modeling of the evolution of steppe chernozems and development of the method of pedogenetic chronology. Eurasian Soil Sci. 49, 846-858.

Lisetskii, F.N., Stolba, V.F., Pichura, V.I., 2017. Late-Holocene palaeoenvironments of Southern Crimea: soils, soil-climate relationship and human impact. Holocene 27, 1859-1875.

Lisetskii, F., Stolba, V., Golyeva, A., Marinina, O., Poletaev, A., 2020. Postantique soils as a source of land use information: a case study of an ancient Greek agricultural area on the northern Black Sea coast. Appl. Environ. Soil Sci. 2020, 8698179.

Lukin, S.V., Tyutyunov, S.I., Yavtushenko, V.E., 2000. Ecological-agrochemical aspects of the use of chemicals in the erodible agrolandscapes of southwestern forest-steppe zone of Russia. Eurasian Soil Sci. 33, S100-S106.

Maslov, S.P., Filin, V.R., 1976. On the environmental conditions of the Chaika settlement environs in antiquity and the Middle Ages. Istorija Biogeocenozov SSSR v Golocene. Nauka, Moscow, pp. 175-182.
Matveev, S.M., Chendev, Yu.G., Lupo, A.R., Hubbart, J.A., Timashchuk, D.A., 2017. Climatic changes in the East-European forest-steppe and effects on Scots pine productivity. Pure Appl. Geophys. 174, 427-443.

Mentzer, S.M., 2014. Microarchaeological approaches to the identification and interpretation of combustion features in prehistoric archaeological sites. J. Archaeol. Method Theor. 21, 616-668.

Miller, N.F., 1984. The use of dung as fuel: an ethnographic example and an archaeological application. Paleorient 10, 71-79.

Miller, S.F., Miller, B.G., 2007. The occurrence of inorganic elements in various biofuels and its effect on ash chemistry and behaviour and use in combustion products. Fuel Process. Technol. 88, 1155-1164.

Mlekuž, D., 2009. The materiality of dung: the manipulation of dung in Neolithic Mediterranean caves. Documenta Praehistorica 36, 219-225.

Moruženko, A.A., 1985. Hillforts of the forest-steppe tribes of the Dnieper-Don interfluve in the 7th through the 3rd century BC. Sovetskaja Archeologija 1, 160-178.

Nosova, L.V., 2008. Antique ash deposits of the northern Black Sea region: eschara-altars or garbage dumps?. In: Kratkie soobščenija Odesskogo archeologičeskogo obščestva, Odessa, pp. 114-136.

Ntinou, M., Tsartsidou, G., 2017. Domestic and ritual use of plants and fuels in the Neolithic cave of Alepotrypa, southern Peloponnese, Greece: the wood charcoal and phytolith evidence. Quat. Int. 457, 211-227.

Petrenko, V.G., 1989. Local groups of a Scythian-like forest-steppe culture of eastern Europe. In: Meljukova, A.I. (Ed.), Stepi evropejskoj časti SSSR v skifo-sarmatskoe vremja. Nauka, Moscow, pp. 67-79.

Pierce, Ch, Adams, K.R., Stewart, J.D., 1998. Determining the fuel constituents of ancient hearth ash via ICP-AES analysis. J. Archaeol. Sci. 25, 493-503.

Podgorodeckij, P.D., 1979. North-Western Crimea. Simferopol.

Portillo, M., Carme Belarte, M., Ramon, J., Kallala, N., Sanmartí, J., Albert, R.M., 2017. An ethnoarchaeological study of livestock dung fuels from cooking installations in northern Tunisia. Quat. Int. 431, 131-144. A.

Powell, A.J., Wheeler, J., Batt, C.M., 2012. Identifying archaeological wood stack charcoal production sites using geophysical prospection: magnetic characteristics from a modern wood stack charcoal burn site. J. Archaeol. Sci. 39, 1197-1204.

Radde, G., 1856. Crimean Tatars. Vestnik Imperatorskogo Russkogo Geografičeskogo Obščstva 18, 290-330.

Rusanova, I.P., 1998. Ritual ash deposits of the Scythian period. Materialy po archeologii, istorii i etnografii Tavrii 6, 160-172.

Rusjaeva, A.S., 2006. Ancient Greek ritual ash deposits in the Lower Bug area. Rossijskaja archeologija 4, 95-102.

Sava, E., 2005a. Die spätbronzezeitlichen Aschenhügel (Zolniki) - ein Erklärungsmodell und einige historisch-wirtschaftliche Aspekte. Prähistorische Zeitschrift 80, 65-109.

Sava, E., 2005b. Viehzucht und Ackerbau in der Noua-Sabatinovka Kultur. Interpretationsraum Bronzezeit. Universitätsforschungen zur Prähistorischen Archäologie 121, 143-159.

Sava, E., Kaiser, E., 2011. Die Siedlung mit Aschehügeln beim Dorf Odaia-Miciurin, Republik Moldova, Chişinău.

Sčeglov, A.N., 1978. North-Western Crimea in Antiquity. Nauka, Leningrad.

Shahack-Gross, R., 2008. Heat of dung-fuelled fires (archived e-mail). In: Miller, N.M. (Ed.), An idiosyncratic and not Exhaustive Bibliography for Animal Dung and Archaeology. http://www.sas.upenn.edu/ nmiller0/dung.html. accessed 15.12.2019.

Shahack-Gross, R., 2011. Herbivorous livestock dung: formation, taphonomy, method for identification, and archaeological significance. J. Archaeol. Sci. 38, 205-218.

Shahack-Gross, R., Albert, R.-M., Gilboa, A., Nagar-Hilman, O., Sharon, I., Weiner, S., 2005. Geoarchaeology in an urban context: the uses of space in a Phoenician monumental building at Tel Dor (Israel). J. Archaeol. Sci. 32, 1417-1431.

Shahack-Gross, R., Ayalon, A., 2013. Stable carbon and oxygen isotopic compositions of wood ash: an experimental study with archaeological implications. J. Archaeol. Sci. 40, 570-578.

Slicher van Bath, H., 1963. The Agrarian History of Western Europe AD 500-1850. Arnold, London.

Smekalova, T.N., Kutajsov, V.A., 2017. Archaeological Atlas of Northwestern Crimea. Late Bronze Age. Early Iron Age. Ancient Greek Period. Aletejja, St. Petersburg.

Smekalova, T.N., Lisetskii, F.N., Buryak, ZhA., 2017. Study of the late Scythian settlement and agricultural-residential complex of Borut-Khane in the piedmon Crimea by natural science methods. Stratum Plus 4, 57-80.

Smekalova, T.N., Stolba, V.F., 2009. Monuments of the Bronze Age and Early Iron Age on the Tarkhankut Peninsula: Preliminary Report. Dolja, Simferopol,

Steenari, B.-M., Schelander, S., Lindqvist, O., 1999. Chemical and leaching characteristics of ash from combustion of coal, peat and wood in a $12 \mathrm{MW}$ CFB - a comparative study. Fuel 78, 249-258.

Stolba, V.F., 2014. Greek Countryside in Ancient Crimea: Chersonesean Chora in the Late Classical to Early Hellenistic Period. Aarhus University, Aarhus.

Stolba, V.F., Andresen, J., 2015. Unveiling the hinterland: a new type of Hellenistic rural settlement in Crimea. Antiquity 89, 345-360.

Takahashi, T., Shoji, S., 2002. Distribution and classification of volcanic ash soils. Glob. Environ. Res. - English Ed. 6 (2), 83-98. 